Subscriber access provided by Caltech Library

\title{
Communication
}

\section{A Terminal Felll-Oxo in a Tetranuclear Cluster: Effects of Distal Metal Centers on Structure and Reactivity}

\author{
Christopher Reed, and Theodor Agapie
}

J. Am. Chem. Soc., Just Accepted Manuscript • DOI: 10.1021/jacs.9b03157 • Publication Date (Web): 14 May 2019

Downloaded from http://pubs.acs.org on May 14, 2019

\section{Just Accepted}

"Just Accepted" manuscripts have been peer-reviewed and accepted for publication. They are posted online prior to technical editing, formatting for publication and author proofing. The American Chemical Society provides "Just Accepted" as a service to the research community to expedite the dissemination of scientific material as soon as possible after acceptance. "Just Accepted" manuscripts appear in full in PDF format accompanied by an HTML abstract. "Just Accepted" manuscripts have been fully peer reviewed, but should not be considered the official version of record. They are citable by the Digital Object Identifier (DOI®). "Just Accepted" is an optional service offered to authors. Therefore, the "Just Accepted" Web site may not include all articles that will be published in the journal. After a manuscript is technically edited and formatted, it will be removed from the "Just Accepted" Web site and published as an ASAP article. Note that technical editing may introduce minor changes to the manuscript text and/or graphics which could affect content, and all legal disclaimers and ethical guidelines that apply to the journal pertain. ACS cannot be held responsible for errors or consequences arising from the use of information contained in these "Just Accepted" manuscripts. 
Terminal metal-oxo moieties are invoked as key intermediates in both natural and synthetic catalysts of mid-first-row transition metal ions (Mn, $\mathrm{Fe}$, and $\mathrm{Co}) .{ }^{1}$ For example in photosynthesis, water is oxidized in photosystem II by a $\mathrm{CaMn}_{4} \mathrm{O}_{5}$ cluster known as the oxygen evolving complex (OEC); ${ }^{2}$ numerous computational studies of the catalytic mechanism have proposed a high-valent Mn-oxo playing a key role in $\mathrm{O}-\mathrm{O}$ bond formation. ${ }^{3}$ Similarly, a number of synthetic water oxidation catalysts employing various multinuclear scaffolds have been reported, where a terminal metal-oxo is implicated as a key intermediate (Figure 1). ${ }^{1 \mathrm{e}-\mathrm{g}, 4}$

Studies of synthetic transition metal-oxo complexes have been integral for understanding these reactive moieties in catalytic systems. ${ }^{1 \text { a, } 5}$ However, there is a paucity of literature concerning multinuclear complexes bearing well-characterized terminal metal-oxo motifs. ${ }^{6}$ In a rare example where the effects of a neighboring metal oxidation state on a terminal metal-oxo could be interrogated, Que and coworkers reported that the spin state of an $\mathrm{Fe}^{\mathrm{IV}}-$ oxo center would change depending on the oxidation state of a neighboring $\mathrm{Fe}$ in a $\mu_{2}-\mathrm{O}$ bridged bimetallic complex $\left(\mathrm{L}_{2}{ }_{2} \mathrm{OFe}_{2}(\mathrm{OH})(\mathrm{O})^{2+/ 3+}\right)$. ${ }^{6 \mathrm{c}}$ The authors demonstrated that structural and spin-state changes due to reduction of this secondary Fe leads to a thousand-fold activation of the $\left[\mathrm{Fe}_{2}\right]$ complex towards $\mathrm{C}-\mathrm{H}$ oxidation.

To gain further insights into these multimetallic effects, our group has examined well-defined tetranuclear clusters of $\mathrm{Fe}$ and $\mathrm{Mn}$, which facilitate intramolecular oxygen atom transfer reactions; however, a terminal metal-oxo intermediate could not be observed. ${ }^{7}$ Inspired by reports of mononuclear terminal metal-oxo motifs stabilized by second coordination sphere hydrogen bonding interactions, ${ }^{8}$ our group has previously used this strategy to access a terminal $\mathrm{Mn}^{\mathrm{III}}-\mathrm{OH}$ moiety as part of a $\left[\mathrm{Mn}_{4}\right]$ cluster. ${ }^{9}$ Herein, we describe the synthesis, structural characterization, and reactivity studies of clusters bearing a terminal $\mathrm{Fe}^{\mathrm{III}}$-oxo motif, stabilized by

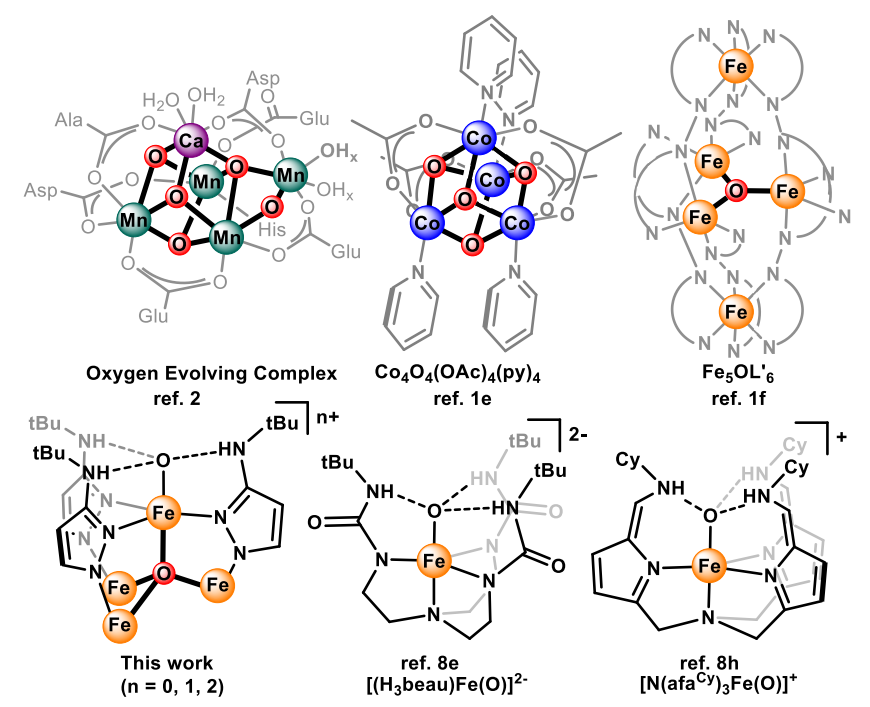

Figure 1. Multinuclear catalysts with proposed terminal metaloxo intermediates (top), and structurally characterized terminal $\mathrm{Fe}^{\mathrm{III}}$-oxo complexes (bottom)

tert-butyl-amino-pyrazolates, to probe the significance of a multinuclear scaffold on structural and reactivity aspects of a terminal metal-oxo.

Treating the reported $\mathbf{L F e}_{3}(\mathbf{O A c})(\mathbf{O T f})_{2}$ cluster (-OTf, triflate = trifluoromethane sulfonate $)^{10}$ with three equivalents of potassium tert-butyl-amino-pyrazolate $(\mathrm{KPzNHtBu})$ and iodosylbenzene ( $\mathrm{PhIO}$ ), followed by addition of iron (II) triflate bis-acetonitrile $\left(\mathrm{Fe}(\mathrm{OTf})_{2} \cdot 2 \mathrm{MeCN}\right)$ and excess potassium hydroxide in tetrahydrofuran produces the neutral $\left[\mathrm{Fe}_{3}^{\mathrm{II}} \mathrm{Fe}^{\mathrm{III}}\right]$ cluster, 1 (Scheme 1). Single crystal X-ray diffraction (XRD) studies of $\mathbf{1}$ reveal a structure similar to our previously reported $\left[\mathrm{Mn}_{4}\right]$ cluster bearing a terminal hydroxide ligand (Figure 2A) $;{ }^{9}$ the apical metal displays a trigonal bipyramidal geometry, with the terminal hydroxide ligand hydrogen bonded to each amino-pyrazolate (N-O distances of 2.826(1), 2.765(1), 2.789(1) $\AA$ for 1). The relatively short distance between the apical Fe and the interstitial $\mu_{4}-\mathrm{O}$ (Fe4-O1), 1.837(1) $\AA$, is consistent with an $\mathrm{Fe}^{\mathrm{III}}$ in the apical position of the cluster, with the remaining $\mathrm{Fe}$ centers being $\mathrm{Fe}^{\mathrm{II}}$. ${ }^{\mathrm{b}}, 11$

The electrochemistry of the $\left[\mathrm{Fe}_{4}\right]$ hydroxide clusters in THF features three quasi-reversible events assigned to the $\left[\mathrm{Fe}_{3}{ }_{3} \mathrm{Fe}^{\mathrm{III}}\right] \rightarrow\left[\mathrm{Fe}^{\mathrm{II}_{2}} \mathrm{Fe}^{\mathrm{III}}{ }_{2}\right] \quad\left(-1.53 \mathrm{~V}\right.$; all potentials vs. $\left.\mathrm{Fc} / \mathrm{Fc}^{+}\right)$, $\left[\mathrm{Fe}_{2}{ }_{2} \mathrm{Fe}^{\mathrm{III}}{ }_{2}\right] \rightarrow\left[\mathrm{Fe}^{\mathrm{II}} \mathrm{Fe}^{\mathrm{III}}{ }_{3}\right](-0.68 \mathrm{~V})$, and $\left[\mathrm{Fe}^{\mathrm{II}} \mathrm{Fe}^{\mathrm{III}}{ }_{3}\right] \rightarrow\left[\mathrm{Fe}^{\mathrm{III}}{ }_{4}\right](-0.10$ V) redox couples (Figure S36). Each of the corresponding oxidation states of the cluster could be isolated (Scheme 1). Mössbauer 
Scheme 1. Synthesis of [Fe $]$ clusters. (Inset) 1,3,5-triarylbenzene ligand platform $\left(\mathrm{L}^{3-}\right)$ and tert-butyl amino pyrazolate ligand (PzNHtBu').
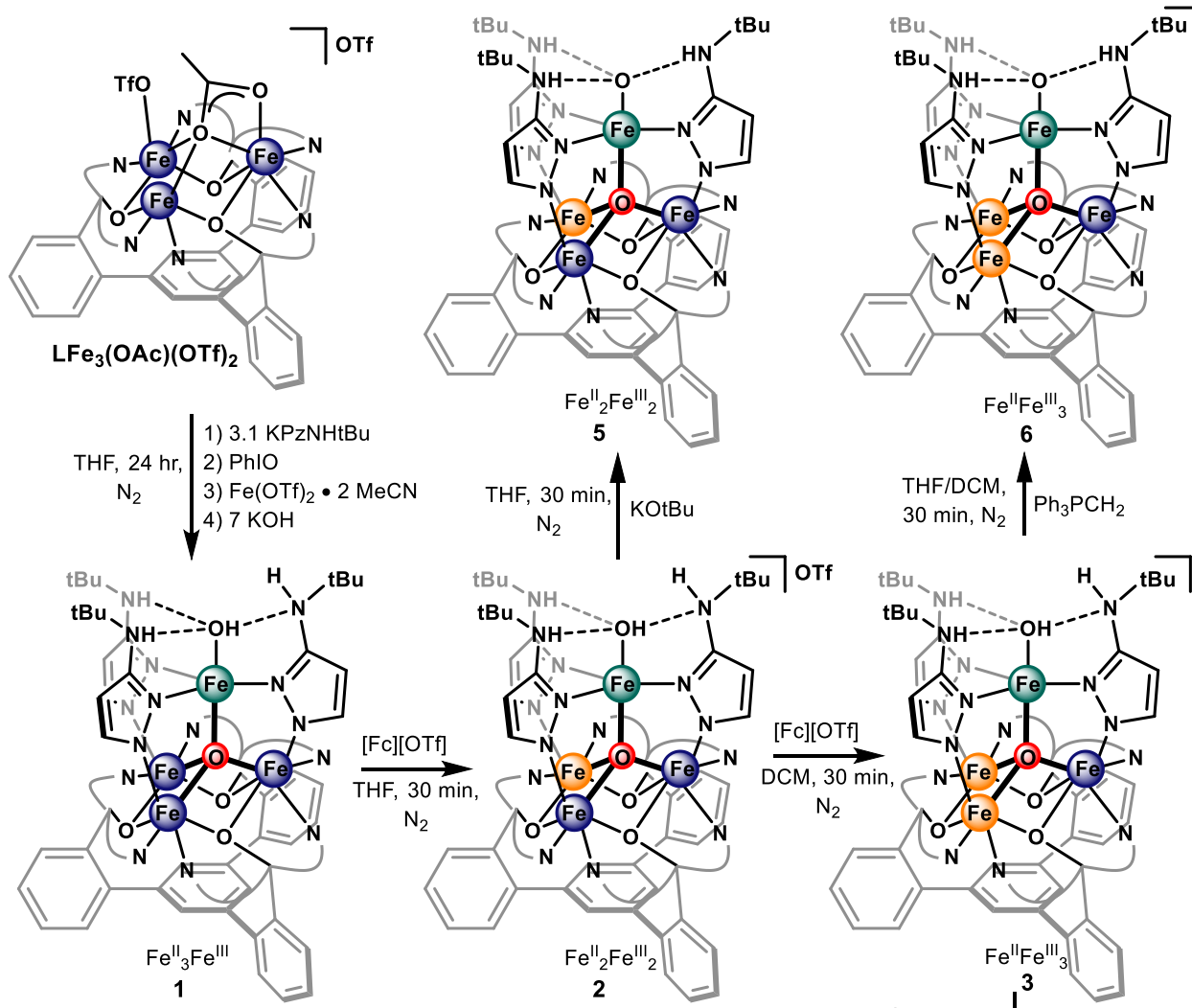

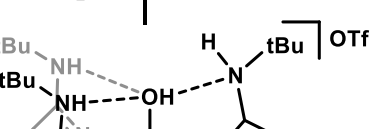
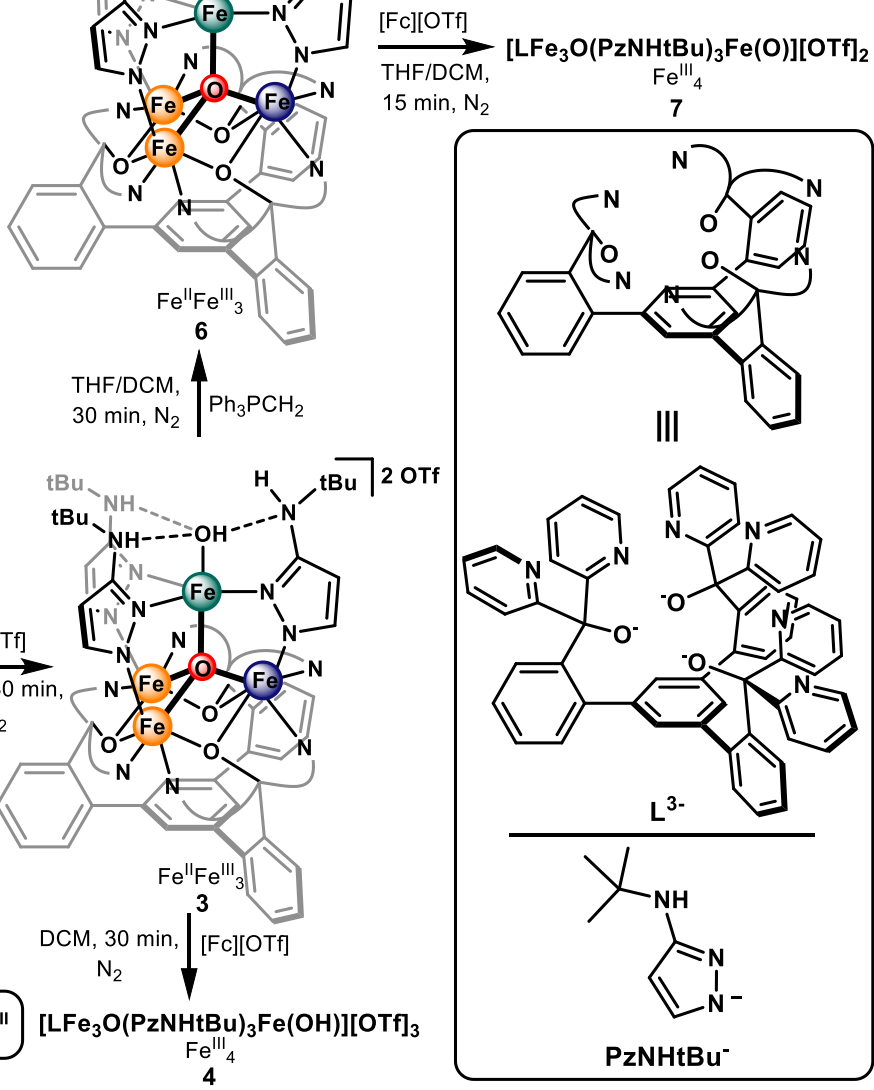

$\mathrm{Fe}=$ six-coordinate $\mathrm{Fe}^{\prime \prime} \mathrm{Fe}=$ six-coordinate $\mathrm{Fe} \mathrm{e}^{\mathrm{II}} \mathrm{Fe}=$ five-coordinate $\mathrm{Fe}^{\mathrm{III}}$

spectra of the oxidized clusters $\mathbf{2}, \mathbf{3}$, and $\mathbf{4}$ are consistent with oxidations occurring at the $\mathrm{Fe}^{\mathrm{II}}$ centers in the tri-iron core and the $\mathrm{Fe}$ $\mathrm{OH}$ moiety remaining $\mathrm{Fe}^{\mathrm{III}}$ (Figures 2C, S42, S46, and S47).

Access to a terminal $\mathrm{Fe}^{\mathrm{III}}$-oxo moiety was achieved by deprotonation of the $\left[\mathrm{Fe}^{\mathrm{II}}{ }_{2} \mathrm{Fe}^{\mathrm{III}}\right.$ 2] hydroxide cluster, 2 , with potassium tertbutoxide (KOtBu; Scheme 1). The resulting compound, 5, was crystallographically characterized (Figure 2B); deprotonation of the hydroxide ligand leads to structural changes to the apical $\mathrm{Fe}$ in 5. The Fe4-O2 distance contracts to $1.817(2) \AA$, compared to the distances in 1 (1.937(1) $\AA$ ) and the precursor 2 (1.907(3) $\AA$ ); this bond length matches closely with the structurally characterized $\mathrm{Fe}^{\mathrm{III}}$-oxo complexes reported by Borovik and Fout. ${ }^{8 \mathrm{e},}{ }^{8 \mathrm{~h}}$, $8 \mathrm{i}$ Compound $\mathbf{6}$, prepared by deprotonating $\mathbf{3}$, also displays a short Fe4O2 distance (1.795(8) $\AA$ ). Furthermore, the apical Fe- $\mu_{4}-\mathrm{O}$ distance (Fe4-O1) elongates to 1.965(2) $\AA$ in 5 and 2.049(7) $\AA$ in 6, from 1.890 (3) $\AA$ in $\mathbf{2}$ and 1.948(2) $\AA$ in $\mathbf{3}$, which is consistent with a greater trans influence exerted by the terminal oxo ligand. The Mössbauer spectra of $\mathbf{5}$ and $\mathbf{6}$ are consistent with the [ $\left.\mathrm{Fe}^{\mathrm{III}}{ }_{2} \mathrm{Fe}^{\mathrm{II}}{ }_{2}\right]$ and $\left[\mathrm{Fe}^{\mathrm{III}}{ }_{3} \mathrm{Fe}^{\mathrm{II}}\right]$ oxidation state assignments, respectively (Figure 2D and S54). The quadrupole doublet assigned to the apical Fe ${ }^{\mathrm{III}}$-oxo centers in $\mathbf{5}$ and $\mathbf{6}$ have parameters distinct from the other previously reported data for $\left[\left(\mathbf{H}_{3} \mathbf{b e a u}\right) \mathbf{F e}(\mathbf{O})\right]^{2-}$, and most other terminal Fe-oxo complexes (Table 1). ${ }^{8 e, 12}$ Further spectroscopic studies of these $\mathrm{Fe}^{\mathrm{III}}$-oxo clusters are underway to understand the source of their atypical Mössbauer parameters.

Terminal $\mathrm{Fe}^{\mathrm{III}}$-oxo complexes are rare, and typically stabilized through hydrogen bonding interactions. ${ }^{8 \mathrm{e}, 8 \mathrm{~h}, 8 \mathrm{i}, 13}$ The structures of 5 and $\mathbf{6}$ display comparable hydrogen bonding distances to other structurally characterized $\mathrm{Fe}^{\mathrm{III}}$-oxo complexes, $\left[\left(\mathrm{H}_{3} \text { beau }\right) \mathrm{Fe}(\mathrm{O})\right]^{2-}$ and $\left[\mathbf{N}\left(\mathbf{a f a}^{\mathrm{Cy}}\right)_{3} \mathbf{F e}(\mathbf{O})\right]^{+}$, along with similar equatorial $\mathrm{Fe}-\mathrm{N}$ distances (Table 1). However, the $\mu_{4}-\mathrm{O}$ distances in $\mathbf{5}(1.965(2) \AA)$ and 6 (2.049(7) $\AA$ ) are significantly shorter than the $\mathrm{Fe}-\mathrm{N}$ distances for the amine trans to the oxo in the mononuclear systems $(\sim 2.27 \AA)$. This is likely a result of greater ligand flexibility in the mononuclear systems; the geometry of these $\mathrm{Fe}^{\mathrm{III}}$-oxo complexes display greater deviations from ideal trigonal bipyramidal geometry compared to the apical $\mathrm{Fe}$ in $\mathbf{5}$ and $\mathbf{6}$, based on a structural index parameter $(\tau$; ideal trigonal bipyramidal geometry $=1.0)$. For the clusters reported here, the rigid geometry of the pyrazolate ligands prevents significant distortion of the apical $\mathrm{Fe}$ out of the equatorial plane.

The hydroxide ligand in $\mathbf{2}$ was determined to be very basic in THF ( $\mathrm{p} K_{a}=30.1$; Table S1). Analogous equilibrium studies were performed on $\mathbf{3}$ and, as expected, oxidation of the cluster reduces the basicity of the $\mathrm{Fe}^{\mathrm{III}}$-oxo moiety $\left(\mathrm{p} K_{a}=23.0\right.$ for 3; Table S2). Attempts to deprotonate $\mathbf{4}$ with various bases, even at low temperatures, only resulted in decomposition, so a $K_{a}$ value for this oxidation state was not measured. These data were combined with electrochemical information for clusters 1 (vide supra) and 5 (Figure S38), to produce thermodynamic square schemes according to equation 1 (Figure 3 ): ${ }^{14}$

$\mathrm{BDE}_{\mathrm{O}-\mathrm{H}}=23.06 E^{\circ}+1.37 \mathrm{p} K_{a}+C$ 

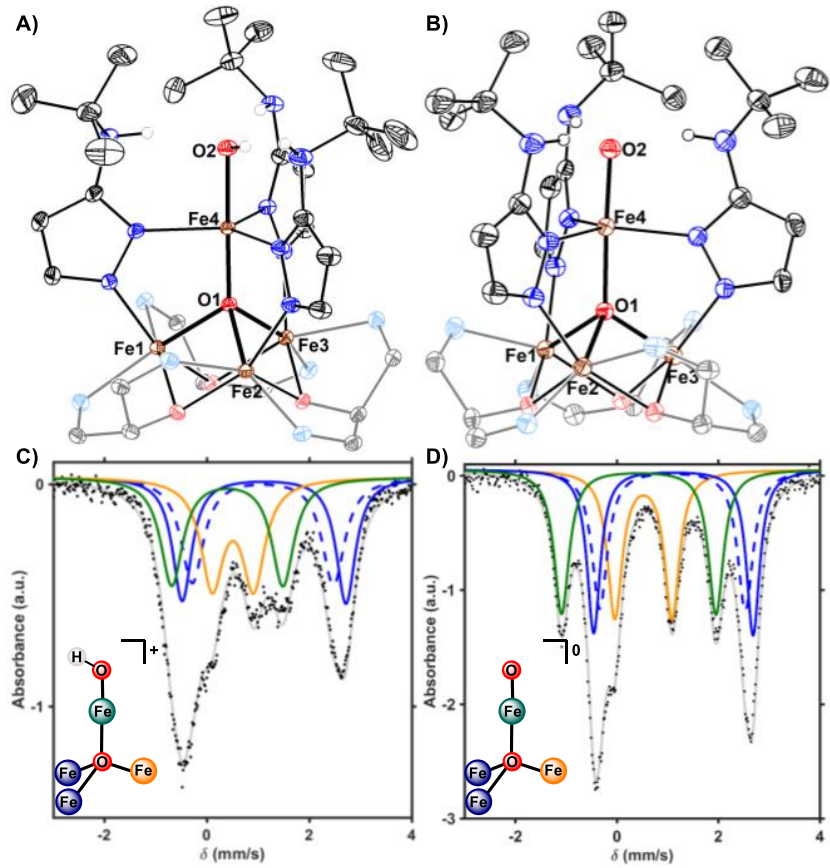

Figure 2. Crystal structures of tetranuclear Fe hydroxide cluster, 1 (A), and oxo cluster, 5 (B). Ellipsoids shown at the $50 \%$ probability level with solvent molecules, and hydrogen atoms (except for $\mathrm{N}-\mathrm{H}$ moieties) omitted for clarity. (C) Mössbauer spectrum of 2 (black dots) with simulated parameters: (i) $\delta=1.12 \mathrm{~mm} / \mathrm{s},\left|\Delta \mathrm{E}_{\mathrm{q}}\right|=3.20$ $\mathrm{mm} / \mathrm{s}$ (solid blue), (ii) $\delta=1.10 \mathrm{~mm} / \mathrm{s},\left|\Delta \mathrm{E}_{\mathrm{q}}\right|=2.76 \mathrm{~mm} / \mathrm{s}$ (dashed blue), (iii) $\delta=0.52 \mathrm{~mm} / \mathrm{s},\left|\Delta \mathrm{E}_{\mathrm{q}}\right|=0.81 \mathrm{~mm} / \mathrm{s}$ (orange), (iv) $\delta=0.41$ $\mathrm{mm} / \mathrm{s},\left|\Delta \mathrm{E}_{\mathrm{q}}\right|=2.17 \mathrm{~mm} / \mathrm{s}$ (green). (D) Mössbauer spectrum of $\mathbf{5}$ (black dots) with simulated parameters: (i) $\delta=1.12 \mathrm{~mm} / \mathrm{s},\left|\Delta \mathrm{E}_{\mathrm{q}}\right|=$ $3.14 \mathrm{~mm} / \mathrm{s}$ (solid blue), (ii) $\delta=1.10 \mathrm{~mm} / \mathrm{s},\left|\Delta \mathrm{E}_{\mathrm{q}}\right|=2.87 \mathrm{~mm} / \mathrm{s}$ (dashed blue), (iii) $\delta=0.52 \mathrm{~mm} / \mathrm{s},\left|\Delta \mathrm{E}_{\mathrm{q}}\right|=1.13 \mathrm{~mm} / \mathrm{s}$ (orange), (iv) $\delta=0.43 \mathrm{~mm} / \mathrm{s},\left|\Delta \mathrm{E}_{\mathrm{q}}\right|=3.04 \mathrm{~mm} / \mathrm{s}$ (green).

$\left[\mathrm{Fe}_{3} \mathrm{Mn}\right]$ hydroxide and aquo clusters, the bond dissociation enthalpy of the $\mathrm{O}-\mathrm{H}$ bond ( $\mathrm{BDE}-\mathrm{H})$ increases upon oxidation of the distal Fe centers, ranging from $72 \mathrm{kcal} / \mathrm{mol}$ in 1 to $84 \mathrm{kcal} / \mathrm{mol}$ in 3. ${ }^{15}$

The three distal $\mathrm{Fe}$ oxidation states have a dramatic effect on the reactivity of the $\mathrm{Fe}^{\mathrm{III}}$-oxo center through modifying the $\mathrm{p} K_{a}$ and Table 1. Selected Bond Distances and Angles, Structural Index Parameter, and Mössbauer Parameters of Reported Fe ${ }^{\mathrm{III}}$-Oxo Complexes

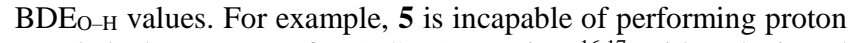
coupled electron transfer (PCET) reactions ${ }^{16,17}$ with substituted phenols over a range of phenol $\mathrm{BDE}_{\mathrm{O}-\mathrm{H}}$ values $(79-85 \mathrm{kcal} / \mathrm{mol})$; only proton transfer to generate $\mathbf{2}$ is observed as expected from the combination of low BDEO-H for $\mathbf{1}$ and high $\mathrm{p} K_{a}$ of $\mathbf{2}$

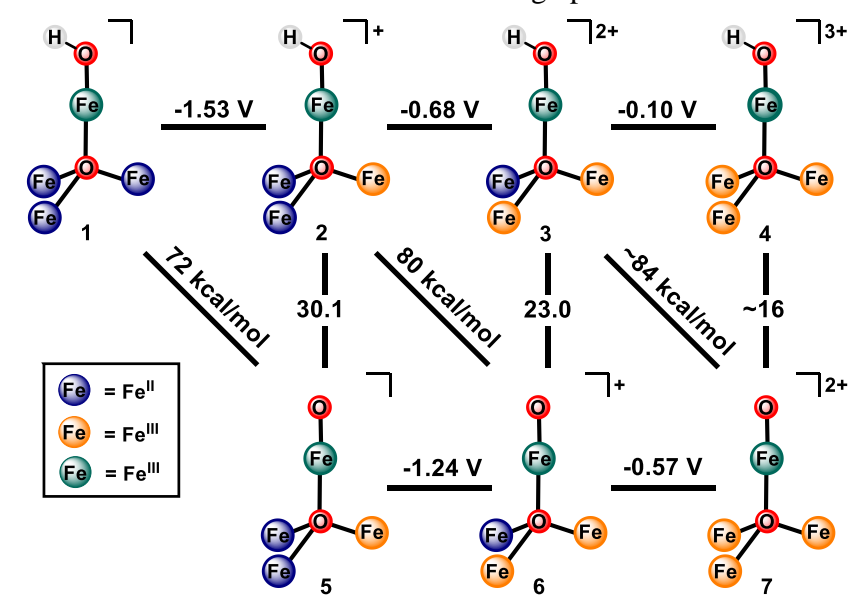

Figure 3. Thermodynamic cycles to evaluate the BDEO-H values of the hydroxide clusters $\mathbf{1}-\mathbf{3}$. Reduction potentials (horizontal lines) are references to $\mathrm{Fc} / \mathrm{Fc}^{+}$. $\mathrm{p} K a$ values (vertical lines) are based on relative $\mathrm{p} K_{a}$ values of cationic acids in THF. Diagonal lines are the BDEO-H values calculated from these parameters according to the Bordwell equation (eq 1). Approximate values ( ) have been extrapolated from the Bordwell equation.

(Figure 3, Table 2 and Figure S13). Oxidation of the remote Fe centers in $\mathbf{6}$ and $\mathbf{7}$ enables PCET reactivity with these phenols (Figures S14 and S16), resulting in the formation of $\mathbf{2}$ and $\mathbf{3}$, respectively.

${ }^{31} \mathrm{P}$ NMR and GC/MS analyses suggest that $\mathbf{7}$ is capable of transferring an oxygen atom to trimethylphoshine $\left(\mathrm{PMe}_{3}\right)$, where the other $\mathrm{Fe}^{\mathrm{III}}$-oxo clusters display no reaction towards the phosphine on similar timescale (see SI). The difference in reactivity is likely due to the low reduction potentials of $\mathbf{5}$ and $\mathbf{6}$ precluding efficient oxygen atom transfer reactivity. A more oxidizing cluster, through oxidations of the distal Fe centers, 7 can undergo OAT.

\begin{tabular}{|c|c|c|c|c|}
\hline & 5 & 6 & {$\left[\left(\mathrm{H}_{3} \text { beau }\right) \mathrm{Fe}(\mathrm{O})\right]^{2-8 e}$} & {$\left[\mathrm{~N}\left(\mathrm{afa}^{\mathrm{Cy}}\right)_{3} \mathrm{Fe}(\mathrm{O})\right]^{+8 \mathrm{~h}}$} \\
\hline $\mathbf{F e}-\mathbf{O}(\AA)$ & $1.817(2)$ & $1.795(8)$ & $1.813(3)$ & $1.806(1)$ \\
\hline $\mathbf{F e}-\mathbf{N}_{\text {equatorial }}(\AA)$ & $\begin{array}{l}2.104(2), 2.098(2), \\
2.093(2)\end{array}$ & $\begin{array}{c}2.100(8), 2.085(9), \\
2.087(9)\end{array}$ & $\begin{array}{c}2.030(4), 2.060(4), \\
2.082(4)\end{array}$ & $\begin{array}{c}2.049(1), 2.049(1), \\
2.052(1)\end{array}$ \\
\hline $\mathbf{F e}-\mathbf{L}_{\text {trans }}(\AA)$ & $1.965(2)\left(\mathrm{L}=\mathrm{O}^{2-}\right)$ & $2.049(7)\left(\mathrm{L}=\mathrm{O}^{2-}\right)$ & $2.271(4)\left(\mathrm{L}=\mathrm{NR}_{3}\right)$ & $2.276(1)\left(\mathrm{L}=\mathrm{NR}_{3}\right)$ \\
\hline N-O (H-bond; ̊̊) & $2.647,2.717,2.685$ & $2.718,2.790,2.750$ & $2.732,2.702,2.686$ & $2.641,2.645,2.673$ \\
\hline$\angle \mathrm{N}_{\text {equatorial }}-\mathrm{Fe}-\mathrm{O}\left(^{\circ}\right)$ & $96.3,92.8,92.0$ & $93.6,97.5,96.3$ & $103.3,99.7,100.8$ & $102.6,103.1,103.1$ \\
\hline $\mathbf{F e}-\mathbf{N}\left|\mathbf{N}^{\prime}\right| \mathbf{N}^{\prime}$ equatorial $(\AA)$ & 0.14 & 0.22 & 0.42 & 0.45 \\
\hline $\begin{array}{l}\text { Structural Index } \\
\text { Parameter }(\tau)^{\mathrm{a}}\end{array}$ & 0.9 & 0.8 & 0.5 & 0.4 \\
\hline $\begin{array}{l}\text { Mossbauer parameters } \\
\qquad(\mathrm{mm} / \mathbf{s})\end{array}$ & $\delta=0.43,\left|\Delta \mathrm{E}_{\mathrm{q}}\right|=3.04$ & $\delta=0.47,\left|\Delta \mathrm{E}_{\mathrm{q}}\right|=2.53$ & $\delta=0.30,\left|\Delta \mathrm{E}_{\mathrm{q}}\right|=0.91$ & - \\
\hline
\end{tabular}


Table 2. Reactivity of the [Fe 4 -Oxo Clusters, 5 - 7.

\begin{tabular}{|c|c|c|c|c|}
\hline & \multirow{2}{*}{$\begin{array}{c}\text { BDE } \\
(\mathrm{kcal} / \mathrm{mol})\end{array}$} & \multicolumn{3}{|c|}{ Reactivity Observed $^{a}$} \\
\hline & & $\frac{5}{\left(\mathrm{Fe}^{\mathrm{II}}{ }_{2} \mathrm{Fe}^{\mathrm{III}}{ }_{2}\right)}$ & $\begin{array}{c}6 \\
\left(\mathrm{Fe}^{\mathrm{II}}\right. \\
\left.\mathrm{Fe}^{\mathrm{III}}{ }_{3}\right)\end{array}$ & $\begin{array}{c}7 \\
\left(\mathrm{Fe}^{\mathrm{III}} 4\right)\end{array}$ \\
\hline $\begin{array}{l}\text { 9,10-dihy- } \\
\text { droanthra- } \\
\text { cene }\end{array}$ & 78 & PCET & PCET & PCET \\
\hline fluorene & 82 & PCET & PCET & PCET \\
\hline $\begin{array}{c}\text { 2,4,6-tBu} 3_{3-}^{-} \\
\mathrm{PhOH}\end{array}$ & 82 & PT & PCET & PCET \\
\hline $\mathrm{PMe}_{3}$ & - & NR & NR & OAT \\
\hline
\end{tabular}

${ }^{a} \mathrm{PT}=$ proton transfer, $\mathrm{PCET}=$ proton-coupled electron transfer (based on cluster products), $\mathrm{OAT}=$ oxygen atom transfer, $\mathrm{NR}=$ no reaction observed. ${ }^{b}$ Second-order rate constant.

The kinetics of $\mathrm{C}-\mathrm{H}$ activation by these clusters was investigated. The reaction between $\mathbf{5}$ and 9,10-dihydroanthracene (DHA; $\left.\mathrm{BDE}_{\mathrm{C}-\mathrm{H}}=78 \mathrm{kcal} / \mathrm{mol}\right)^{14 \mathrm{c}}$ displays an expected first order dependence on substrate concentration, with an overall second order rate constant of $87 \mathrm{M}^{-1} \mathrm{~s}^{-1}$, and a considerable kinetic isotope effect (KIE) of 7 with $d_{4}$-DHA. These data are consistent with a rate-limiting $\mathrm{C}-\mathrm{H}$ bond activation for the PCET process to form $\mathbf{1}$ and anthracene. The second-order rate constants between $\mathbf{5}$ and $\mathrm{C}-\mathrm{H}$ bonds of varying $\mathrm{BDE}_{\mathrm{C}-\mathrm{H}}$ and $\mathrm{p} K_{a}$ values were measured and display a linear dependence of the PCET reaction rate on the $\mathrm{p} K_{a}$ of the organic substrate (Figure 4), suggesting either a concerted or stepwise $\mathrm{p} K_{a}$-driven process. ${ }^{18}$ Reactions between DHA and $\mathbf{6}$ or 7 produce the corresponding hydroxide-clusters and anthracene in yields comparable to 5 (Table S3) indicating PCET processes, but complex kinetics precluded the determination of rate constants and further insights into the mechanism of these reactions.

Overall, this report offers a rare systematic study of the effects of neighboring redox active metals on structural and reactivity aspects of a terminal metal-oxo. Because it is part of a cluster, the reactivity of the terminal metal-oxo motif can be tuned without changing the formal redox state of the metal supporting it; however, redox events at distal centers have significant effect on the acidity and BDE of the corresponding O-H bond. Clearly, the cluster as an assembly is essential for reactivity beyond the structural aspects of the isolated metal-oxo motif. Further development of multinuclear model systems is necessary to fully understand the nature and amplitude of these effects.

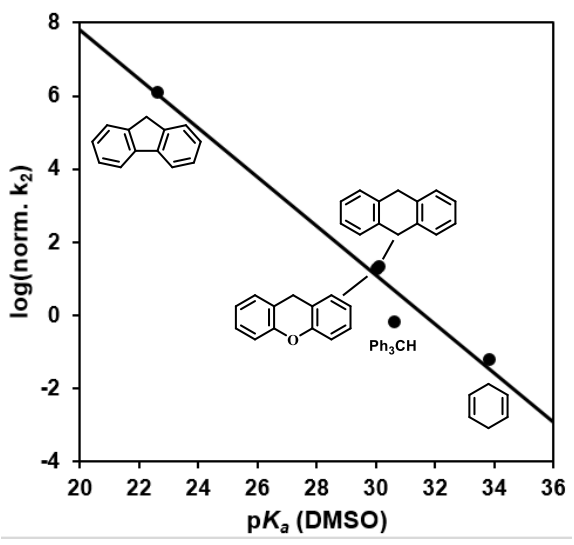

Figure 4. Plot of $\log \mathrm{k}_{2}$ (normalized to number of reactive $\mathrm{C}-\mathrm{H}$ bonds) versus reported $\mathrm{p} K_{a}$ values of the organic substrates in DMSO for PCET reactions with $\mathbf{5}$.

\section{ASSOCIATED CONTENT}

\section{Supporting Information}

The Supporting Information is available free of charge on the ACS Publications website.

Experimental Procedures and Supplimentary Data (PDF) Crystallographic data files (CIFs)

\section{AUTHOR INFORMATION}

\section{Corresponding Author \\ *agapie@caltech.edu}

\section{Notes}

The authors declare no competing financial interests.

\section{ACKNOWLEDGMENT}

This research was supported by the NIH (R01-GM102687B) and the Dreyfus Teacher-Scholar Program (T.A.). C.J.R. thanks the Resnick Sustainability Institute at Caltech for a fellowship. We thank Dr. Mike Takase and Larry Henling for assistance with crystallography, Prof. Jonas Peters for use of his group's Mössbauer spectrometer, and the Dow Next Generation Educator Fund for instrumentation.

\section{REFERENCES}

1. (a) Que Jr, L.; Tolman, W. B., Biologically inspired oxidation catalysis. Nature 2008, 455, 333; (b) Hohenberger, J.; Ray, K.; Meyer, K., The biology and chemistry of high-valent iron-oxo and iron-nitrido complexes. Nature Communications 2012, 3, 720; (c) Costas, M.; Mehn, M. P.; Jensen, M. P.; Que, L., Dioxygen activation at mononuclear nonheme iron active sites: enzymes, models, and intermediates. Chem. Rev. 2004, 104 (2), 939-986; (d) Blakemore, J. D.; Crabtree, R. H.; Brudvig, G. W., Molecular catalysts for water oxidation. Chem. Rev. 2015, 115 (23), 1297413005; (e) Nguyen, A. I.; Ziegler, M. S.; Oña-Burgos, P.; SturzbecherHohne, M.; Kim, W.; Bellone, D. E.; Tilley, T. D., Mechanistic investigations of water oxidation by a molecular cobalt oxide analogue: evidence for a highly oxidized intermediate and exclusive terminal oxo participation. J. Am. Chem. Soc. 2015, 137 (40), 12865-12872; (f) Okamura, M.; Kondo, M.; Kuga, R.; Kurashige, Y.; Yanai, T.; Hayami, S.; Praneeth, V. K. K.; Yoshida, M.; Yoneda, K.; Kawata, S.; Masaoka, S., A pentanuclear iron catalyst designed for water oxidation. Nature 2016, 530 (7591), 465-468; (g) Hunter, B. M.; Thompson, N. B.; Müller, A. M.; Rossman, G. R.; Hill, M. G.; Winkler, J. R.; Gray, H. B., Trapping an iron(VI) water-splitting intermediate in nonaqueous media. Joule 2018, 2 (4), 747-763.

2. Yano, J.; Yachandra, V., $\mathrm{Mn}_{4} \mathrm{Ca}$ cluster in photosynthesis: where and how water is oxidized to dioxygen. Chem. Rev. 2014, 114 (8), 4175-4205.

3. (a) Ichino, T.; Yoshioka, Y., Theoretical study on mechanism of dioxygen evolution in photosystem II. II. Molecular and electronic structures at the $\mathrm{S}_{3}$ and $\mathrm{S}_{4}$ states of oxygen-evolving complex. Chem. Phys. Lett. 2014, 595-596, 237-241; (b) Yamaguchi, K.; Isobe, H.; Yamanaka, S.; Saito, T.; Kanda, K.; Shoji, M.; Umena, Y.; Kawakami, K.; Shen, J. R.; Kamiya, N.; Okumura, M., Full geometry optimizations of the mixedvalence $\mathrm{CaMn}_{4} \mathrm{O}_{4} \mathrm{X}\left(\mathrm{H}_{2} \mathrm{O}\right)_{4}(\mathrm{X}=\mathrm{OH}$ or $\mathrm{O})$ cluster in OEC of PS II: Degree of symmetry breaking of the labile Mn-X-Mn bond revealed by several hybrid DFT calculations. Int. J. Quantum Chem 2013, 113 (4), 525-541; (c) Sproviero, E. M.; Gascón, J. A.; McEvoy, J. P.; Brudvig, G. W.; Batista, V. S., Quantum mechanics/molecular mechanics study of the catalytic cycle of water splitting in photosystem II. J. Am. Chem. Soc. 2008, 130 (11), 34283442; (d) Siegbahn, P. E. M., Water oxidation mechanism in photosystem II, including oxidations, proton release pathways, $\mathrm{O}-\mathrm{O}$ bond formation and $\mathrm{O}_{2}$ release. BBA - Bioenergetics 2013, 1827 (8), 1003-1019.

4. $\quad$ Limburg, J.; Vrettos, J. S.; Liable-Sands, L. M.; Rheingold, A. L.; Crabtree, R. H.; Brudvig, G. W., A functional model for O-O bond formation by the $\mathrm{O}_{2}$-evolving complex in photosystem II. Science 1999, 283 (5407), 1524-1527. 
5. (a) Ozaki, S.-i.; Roach, M. P.; Matsui, T.; Watanabe, Y. Investigations of the roles of the distal heme environment and the proximal heme iron ligand in peroxide activation by heme enzymes via molecular engineering of myoglobin. Acc. Chem. Res. 2001, 34 (10), 818-825; (b) Betley, T. A.; Wu, Q.; Van Voorhis, T.; Nocera, D. G., Electronic design criteria for $\mathrm{O}-\mathrm{O}$ bond formation via metal-oxo complexes. Inorg. Chem. 2008, 47 (6), 1849-1861; (c) Guo, M.; Corona, T.; Ray, K.; Nam, W., Heme and Nonheme High-Valent Iron and Manganese Oxo Cores in Biological and Abiological Oxidation Reactions. ACS Cent Sci 2019, 5 (1), 13-28; (d) Sacramento, J. J. D.; Goldberg, D. P., Factors affecting hydrogen atom transfer reactivity of metal-oxo porphyrinoid complexes. Acc. Chem. Res. 2018, 51 (11), 2641-2652; (e) Goetz, M. K.; Hill, E. A.; Filatov, A. S.; Anderson, J. S., Isolation of a terminal Co(III)-oxo complex. J. Am. Chem. Soc. 2018, 140 (41), 13176-13180; (f) Usharani, D.; Janardanan, D.; Li, C.; Shaik, S., A theory for bioinorganic chemical reactivity of oxometal complexes and analogous oxidants: the exchange and orbital-selection rules. Acc. Chem. Res. 2013, 46 (2), 471-482; (g) Kim, S. H.; Park, H.; Seo, M. S.; Kubo, M.; Ogura, T.; Klajn, J.; Gryko, D. T.; Valentine, J. S.; Nam, W., Reversible $\mathrm{O}-\mathrm{O}$ bond cleavage and formation between $\mathrm{Mn}$ (IV)-peroxo and Mn(V)-oxo corroles. J. Am. Chem. Soc. 2010, 132 (40), 14030-14032; (h) Kurahashi, T.; Kikuchi, A.; Shiro, Y.; Hada, M.; Fujii, H., Unique properties and reactivity of high-valent manganese-oxo versus manganese-hydroxo in the salen platform. Inorg. Chem. 2010, 49 (14), 6664-6672; (i) Gunay, A.; Theopold, K. H., C-H bond activations by metal oxo compounds. Chem. Rev. 2010, 110 (2), 1060-1081.

6. (a) de Visser, S. P.; Kumar, D.; Neumann, R.; Shaik, S., Computer-generated high-valent iron-oxo and manganese-oxo species with polyoxometalate ligands: how do they compare with the iron-oxo active species of heme enzymes? Angew. Chem. Int. Ed. 2004, 43 (42), 5661-5665; (b) Khenkin, A. M.; Kumar, D.; Shaik, S.; Neumann, R., Characterization of manganese $(\mathrm{V})$-oxo polyoxometalate intermediates and their properties in oxygen-transfer reactions. J. Am. Chem. Soc. 2006, 128 (48), 15451-15460; (c) Xue, G.; De Hont, R.; Münck, E.; Que, L., Jr., Million-fold activation of the $\left[\mathrm{Fe}_{2}(\mu-\mathrm{O})_{2}\right]$ diamond core for $\mathrm{C}-\mathrm{H}$ bond cleavage. Nature Chemistry 2010, 2 (5), 400-405; (d) Vaddypally, S.; Kondaveeti, S. K.; Karki, S.; Van Vliet, M. M.; Levis, R. J.; Zdilla, M. J., Reactive pendant $\mathrm{Mn}=\mathrm{O}$ in a synthetic structural model of a proposed $\mathrm{S}_{4}$ state in the photosynthetic oxygen evolving complex. J. Am. Chem. Soc. 2017, 139 (13), 4675-4681; (e) Sarma, R.; Angeles-Boza, A. M.; Brinkley, D. W.; Roth, J. P., Studies of the di-iron(VI) intermediate in ferratedependent oxygen evolution from water. J. Am. Chem. Soc. 2012, 134 (37), 15371-15386.

7. (a) Carsch, K. M.; de Ruiter, G.; Agapie, T., Intramolecular C$\mathrm{H}$ and $\mathrm{C}-\mathrm{F}$ bond oxygenation by site-differentiated tetranuclear manganese models of the OEC. Inorg. Chem. 2017, 56 (15), 9044-9054; (b) de Ruiter, G.; Thompson, N. B.; Takase, M. K.; Agapie, T., Intramolecular C-H and $\mathrm{C}-\mathrm{F}$ bond oxygenation mediated by a putative terminal oxo species in tetranuclear iron complexes. J. Am. Chem. Soc. 2016, 138 (5), 1486-1489; (c) de Ruiter, G.; Carsch, K. M.; Gul, S.; Chatterjee, R.; Thompson, N. B.; Takase, M. K.; Yano, J.; Agapie, T., Accelerated oxygen atom transfer and $\mathrm{C}-\mathrm{H}$ bond oxygenation by remote redox changes in $\mathrm{Fe}_{3} \mathrm{Mn}$-iodosobenzene adducts. Angew. Chem. Int. Ed. 2017, 56 (17), 4772-4776.

8. (a) Lacy, D. C.; Gupta, R.; Stone, K. L.; Greaves, J.; Ziller, J. W.; Hendrich, M. P.; Borovik, A. S., Formation, structure, and EPR detection of a high spin $\mathrm{Fe}^{\mathrm{IV}}$ - oxo species derived from either an $\mathrm{Fe}^{\mathrm{III}}$ oxo or Fe ${ }^{\mathrm{III}}-\mathrm{OH}$ complex. J. Am. Chem. Soc. 2010, 132 (35), 1218812190; (b) Gupta, R.; Taguchi, T.; Lassalle-Kaiser, B.; Bominaar, E. L.; Yano, J.; Hendrich, M. P.; Borovik, A. S., High-spin Mn-oxo complexes and their relevance to the oxygen-evolving complex within photosystem II. Proc. Natl. Acad. Sci. 2015, 112 (17), 5319-5324; (c) Gupta, R.; MacBeth, C. E.; Young, V. G.; Borovik, A. S., Isolation of monomeric $\mathrm{Mn}^{\mathrm{III} / \mathrm{II}}-\mathrm{OH}$ and $\mathrm{Mn}^{\mathrm{III}}-\mathrm{O}$ complexes from water: evaluation of $\mathrm{O}-\mathrm{H}$ bond dissociation energies. J. Am. Chem. Soc. 2002, 124 (7), 1136-1137; (d) Gupta, R.; Borovik, A. S., Monomeric $\mathrm{Mn}^{\mathrm{III/II}}$ and $\mathrm{Fe}^{\mathrm{III/II}}$ complexes with terminal hydroxo and oxo ligands: probing reactivity via $\mathrm{O}-\mathrm{H}$ bond dissociation energies. J. Am. Chem. Soc. 2003, 125 (43), 13234-13242; (e) MacBeth, C. E.; Golombek, A. P.; Young, V. G.; Yang, C.; Kuczera, K.; Hendrich, M. P.; Borovik, A. S., $\mathrm{O}_{2}$ activation by nonheme iron complexes: a monomeric $\mathrm{Fe}(\mathrm{III})-$-oxo complex derived from $\mathrm{O}_{2}$. Science 2000, 289 (5481), 938-941; (f) Ford, C. L.; Park, Y. J.; Matson, E. M.; Gordon, Z.; Fout, A. R., A bioinspired iron catalyst for nitrate and perchlorate reduction. Science $\mathbf{2 0 1 6}$, 354 (6313), 741; (g) Park, Y. J.; Matson, E. M.; Nilges, M. J.; Fout, A. R., Exploring $\mathrm{Mn}-\mathrm{O}$ bonding in the context of an electronically flexible secondary coordination sphere: synthesis of a Mn(III)-oxo. Chem. Commun. 2015, 51 (25), 5310-5313; (h) Matson, E. M.; Park, Y. J.; Fout, A. R., Facile nitrite reduction in a non-heme iron system: formation of an iron(III)-Oxo. J. Am. Chem. Soc. 2014, 136 (50), 17398-17401; (i) Gordon, Z.; Drummond, M. J.; Matson, E. M.; Bogart, J. A.; Schelter, E. J.; Lord, R. L.; Fout, A. R., Tuning the Fe(II/III) redox potential in nonheme $\mathrm{Fe}(\mathrm{II})-$ hydroxo complexes through primary and secondary coordination sphere modifications. Inorg. Chem. 2017, 56 (9), 4852-4863.

9. Han, Z.; Horak, K. T.; Lee, H. B.; Agapie, T., Tetranuclear manganese models of the OEC displaying hydrogen bonding interactions: application to electrocatalytic water oxidation to hydrogen peroxide. $J$. Am. Chem. Soc. 2017, 139 (27), 9108-9111.

10. de Ruiter, G.; Thompson, N. B.; Lionetti, D.; Agapie, T., Nitric oxide activation by distal redox modulation in tetranuclear iron nitrosyl complexes. J. Am. Chem. Soc. 2015, 137 (44), 14094-14106.

11. Arnett, C. H.; Chalkley, M. J.; Agapie, T., A thermodynamic model for redox-dependent binding of carbon monoxide at sitedifferentiated, high spin iron clusters. J. Am. Chem. Soc. 2018, 140 (16), 5569-5578.

12. McDonald, A. R.; Que Jr, L., High-valent nonheme iron-oxo complexes: synthesis, structure, and spectroscopy. Coord. Chem. Rev. 2013, 257 (2), 414-428.

13. Andris, E.; Navrátil, R.; Jašík, J.; Puri, M.; Costas, M.; Que, L.; Roithová, J., Trapping iron(III)-oxo species at the boundary of the "Oxo Wall": insights into the nature of the Fe(III)-O bond. J. Am. Chem. Soc. 2018, 140 (43), 14391-14400.

14. (a) Bordwell, F. G.; Satish, A. V.; Zhang, S.; Zhang, X. M., Using thermodynamic cycles to study reactive intermediates. In Pure Appl. Chem., 1995; Vol. 67, p 735; (b) Mayer, J. M., Hydrogen Atom Abstraction by Metal-Oxo Complexes: Understanding the Analogy with Organic Radical Reactions. Acc. Chem. Res. 1998, 31 (8), 441-450; (c) Warren, J. J.; Tronic, T. A.; Mayer, J. M., Thermochemistry of proton-coupled electron transfer reagents and its implications. Chem. Rev. 2010, 110 (12), 6961-7001.

15. Reed, C. J.; Agapie, T., Thermodynamics of proton and electron transfer in tetranuclear clusters with $\mathrm{Mn}-\mathrm{OH}_{2} / \mathrm{OH}$ motifs relevant to $\mathrm{H}_{2} \mathrm{O}$ activation by the oxygen evolving complex in photosystem II. J. Am. Chem. Soc. 2018, 140 (34), 10900-10908.

16. PCET is broadly referred to here as the transfer of a proton and an electron to different parts of a complex (see ref. 17); the precise mechanism, whether concerted (CPET or EPT) or stepwise (either PTET or ETPT), is left ambiguous, as the present experiments cannot differentiate them.

17. Weinberg, D. R.; Gagliardi, C. J.; Hull, J. F.; Murphy, C. F.; Kent, C. A.; Westlake, B. C.; Paul, A.; Ess, D. H.; McCafferty, D. G.; Meyer, T. J., Proton-Coupled Electron Transfer. Chem. Rev. 2012, 112 (7), 4016-4093.

18. Goetz, M. K.; Anderson, J. S., Experimental Evidence for p KaDriven Asynchronicity in C-H Activation by a Terminal Co(III)-Oxo Complex. J. Am. Chem. Soc. 2019, 141 (9), 4051-4062. 
Authors are required to submit a graphic entry for the Table of Contents (TOC) that, in conjunction with the manuscript title, should give the reader a representative idea of one of the following: A key structure, reaction, equation, concept, or theorem, etc., that is discussed in the manuscript. Consult the journal's Instructions for Authors for TOC graphic specifications.

\section{Insert Table of Contents artwork here}

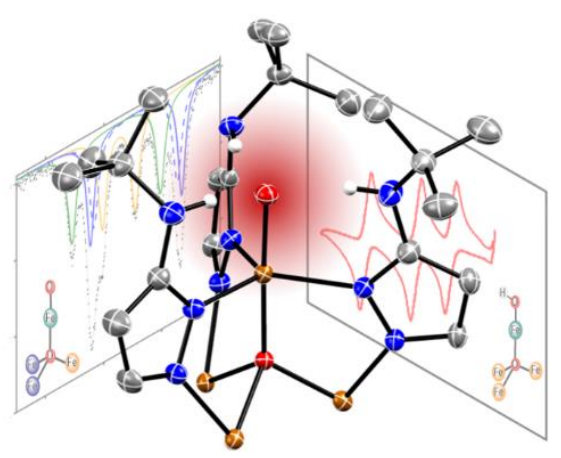

